\title{
Classroom Response Systems as a Formative Assessment Tool: Investigation into Students' Perceived Usefulness and Behavioural Intention
}

\author{
Muhittin Şahin (D) 1,* \\ ${ }^{1}$ Department of Computer Education and Instructional Technology, Ege University, 35040, Izmir, Turkey
}

\author{
ARTICLE HISTORY \\ Received: 15 April 2019 \\ Revised: 26 July 2019 \\ Accepted: 10 November 2019

\section{KEYWORDS} \\ Formative assessment, \\ Classroom response systems, \\ Perceived usefulness, \\ Behavioral intention.
}

\begin{abstract}
Assessments are conducted to determine the effectiveness of learning. One type of these assessments are formative assessment, which aims to fill the gap between the learner's present situation and the desired situation by giving feedback to learners. For this purpose, Classroom Response Systems can be used in large groups. Paper-based tests, Kahoot, Quizizz, and, Plickers were used for formative assessment. Multiple-choice tests can be created for students with these applications. Students can connect to Kahoot and Quizizz applications via any computer, tablet or mobile phones with an internet connection and answer the questions in the test. For the Plickers application, the questions are displayed by the instructor in an area that all students can see. Students indicate their responses by lifting their paper which has QR code. The instructor scans these QR codes with the help of a mobile device and the students' answers are seen directly. In this context, the perceived usefulness and behavioral intention of the students to use different classroom response systems were investigated. The research was conducted with freshman students at a state university and continued for four weeks. Different applications were presented to the students as like that a paper-based test, Kahoot, Quizizz, and Plickers. When the findings were examined, it was found that students noted Kahoot, Quizizz, and Plickers applications were statistically more useful than the paper-based test. Based on these results, it can be said that students prefer to use technology-supported classroom response systems instead of the paper-based test.
\end{abstract}

\section{INTRODUCTION}

Assessment is a basic component of effective learning (Bransford, Brown, \& Cocking, 2000). there were two instructional assessments as formative and summative in the past. Nowadays assessment was reclassified as Assessment of Learning (AoL), Assessment for Learning (AfL) and Assessment as Learning (AaL). While AoL corresponds to the summative assessment (SA), the formative assessment (FA) is divided into two subgroups as AfL and AaL. FA aims to reform the learning (Bayrak \& Yurdugül, 2016). One of the foundation of FA is to fill the gap between the desired purpose and the existing situation of the learner (Black \& Wiliam, 1998).

CONTACT: Muhittin Şahin $\square$ muhittin.sahin@ege.edu.tr $\equiv$ Department of Computer Education and Instructional Technology, Ege University, 35040, Izmir, TURKEY 
Formative assessment is a process in which various tools and strategies are used to determine what the student knows, to improve learning and to plan future teaching (Pinchok \& Brandt, 2009). Quality feedback is the key feature of FA (Black \& Wiliam, 1998). Feedback contains important information about students' learning. This information is important for the instructor (AfL) to restructure teaching, and important for students (AaL) to increase their learning awareness and improvelearning experiences.

However, due to the crowded classrooms, the instructors have some problems in both preparing questions and giving feedback about missing concepts (Bayrak \& Yurdugül, 2016). At this point, classroom response systems (CRS) which can be applied to large masses, helped to solve this problem. It is possible to give immediate and quality feedback to the students and instructors through CRS (Kay, 2009; Lucke, Keyssner, \& Dunn, 2013; Fuller \& Dawson, 2017). Within the scope of this research, CRSs are discussed in the context of FA because by nature these systems are used for formative assessment (Beatty, Gerace, Leonard, \& Dufresne, 2006).

Determination of perceived usefulness and behavioral intention are important for using the CRSs. These concepts are explained by acceptance and adoption theories and models. Perceived usefulness, ease of use, facilitating conditions and social influence factors play an important role in acceptance and adoption theories and models (Usluel \& Mazman, 2010). And also, the level of perceived usefulness by the individual about innovation is directly related to use (Rogers, 2003). Therefore, in the context of this research, perceived usefulness and behavioral intention were included. Usluel and Mazman (2010) define perceived usefulness as the belief that individuals will increase performance by using something new. Behavioral intention is defined as individual readiness of display behavior (Fishbein \& Ajzen, 1975). Within the scope of this study, perceived usefulness and behavioral intention about different classroom response systems were investigated.

\subsection{Classroom Response System (CRS)}

It is seen that CRS has a history of approximately 60 years. The purpose of these systems, which were introduced in the 1960s (called electronic response systems in the 1960s), is to give learners immediate feedback on multiple-choice questions and to inform teachers about the understanding of learners (Judson \& Sawada, 2002). It is possible to determine which concepts are missing or misunderstood by the learners through feedback presented to the instructors. It also provides feedback to instructors on what subjects are needed for extra teaching and in which topics students are successful (Bartsch \& Murphy, 2011). In addition, the instructors can provide information about the item difficulty and item discrimination, or information about distractors. And also, the systems can provide feedback to learners about individual shortcomings.

CRSs are technologies which used to encourage active learning (Martyn, 2007). Through integrating the CRS to curriculum design, a new communication channel is provided and the classroom interaction between the learner and the instructor can be changed (Siau, Sheng, \& Nah, 2006). CRSs are enjoyable and helpful systems that create a communication channel between learners and tutorials in very large classroom environments (Vetterick, Garbe, Dähn, $\&$ Cap, 2014). These systems can be used in very large masses or with small groups. CRS has the following features;

- Presentation and ask questions

- Learner response and display

- Data management and analysis (Deal, 2007).

Using CRS has some difficulties and researchers should pay attention to these issues. These difficulties are expressed by Feldman and Capobianco (2003) as follows: 
- Create and adaptive appropriate questions

- Create productive classroom environments

The quality of the questions which are prepared in these systems is very important. The learning environment must be increased learner engagement and giving adequate time to students for responding to the questions (Lucke, Keyssner, \& Dunn, 2013). Learning environments should be provided with a high level of interaction in order to provide productive classroom environments. In this context, two important characteristics of interaction communication and engagement are encountered (Sims, 2003). In other words, learning environments must be haven some features as increase engagement and encoure communication.

In the literature, it's seen that; CRSs increase learner engagement, participant, and peer interaction (Martyn, 2007; Lucke, Keyssner, \& Dunn, 2013; Petto, 2019; Cheng \& Wang, 2019; Y1lmaz \& Karaoğlan Y1lmaz, 2019). Another result is that these systems contribute to learning outcomes by increasing their interaction with lectures, tutorials, and other learners (Bartsch \& Murphy, 2011; Lucke, Keyssner, \& Dunn, 2013; Yang et al., 2019). The literature review study shows that (Kay \& LeSage, 2009);

- In general, learners have a positive attitude.

- In the classroom, these systems increased participation, attention, and engagement.

- In the context of learning, it provides interaction and discussion environments, improves learning performance and quality of learning.

- Giving feedback, formative assessment, and compare features are expressed as positive characteristics

Recently, it is possible to say that CRS development and diversity have increased through the improvement of web technologies. As a question type in addition to multiple-choice questions, drag-and-drop, puzzle, and similar applications can also be developed. In addition to integrating the elements of gamification into the systems, more enjoyable and entertaining environments have been started to be developed. In the context of data management and analysis, not only descriptive analysis but also more advanced analysis and presentation of this information have become feasible.

The aim of this study, determining perceived usefulness and behavioral intention levels of using different classroom response systems by students. For this purpose, the following sub-problems were tried to response:

I. Are there any differences in learners' perceived usefulness levels about different CRS?

II. Are there any differences in learners' behavioral intention levels about different CRS?

\section{METHOD}

In this section research design, participants, data collection tools, data analysis, implementation process and, CRSs used for this study are presented.

\subsection{Research Design}

This study was structured as survey research. The main purpose of survey research studies is to define the character in a sample (Fraenkel, Wallen, \& Hyun, 2011). Within the scope of this research, the perceived usefulness and behavioral intention of using different classroom response systems by students were tried to be determined.

\subsection{Participants}

The participants of the research are junior students who are assigned Information Technologies course at a public university. Different applications were presented to the students as like that a paper-based test, Kahoot, Quizizz, and Plickers. Respectively, 61, 60, 59 and 54 students participated in these applications. Participants were from three different departments as 
Preschool Education, Social Sciences Education, and Guidance and Counseling. The data collection tool was applied to the students at different times after each application. So there are four demographic information about the participants. Detailed information about the participants is presented in the findings section.

\subsection{Data Collection Tools}

"Computer Based Assessment Acceptance Model Scale" was used as data collection tools. The scale includes six factors as "perceived usefulness, perceived ease of use, computer self-efficacy, social impact, content, and behavioral intention". But within the scope of this research, is limited to only two factors. The scale developed by Yurdugül and Bayrak (2014) was used in order to determine the characteristics of students' perceived usefulness and behavioral intention. There are three items for perceived usefulness and three items for behavioral intention factors. The scale form was a five-point Likert scale as "Strongly Agree (5)", "Agree (4)", "Undecided (3)", "Disagree (2)" and "Strongly Disagree (1)". The Cronbach Alpha reliability coefficient for the behavioral intention 0,89 and for the perceived usefulness 0,90 was calculated by Yurdugül and Bayrak (2014). Within the scope of this research, Cronbach Alpha reliability coefficients were calculated for each application separately. The obtained reliability coefficients are presented in Table 1.

Table 1. Cronbach Alpha reliability coefficients of the factors

\begin{tabular}{lcccc}
\hline Structure & Paper-based test & Kahoot & Quizizz & Plickers \\
\hline Behavioral intention & 0,93 & 0,94 & 0,91 & 0,94 \\
Perceived usefulness & 0,88 & 0,80 & 0,83 & 0,76 \\
\hline
\end{tabular}

According to Table 1, the reliability coefficients are between 0,76 and 0,94 for the scale structures. If these coefficients are greater than 0,70 , the results are reliable (Nunnally \& Bernstein, 1994; as cited in Yurdugül \& Bayrak, 2014). It is possible to say that the factors are reliable.

\subsection{Data Analysis}

In order to determine differences in the students' perceptions of usefulness and behavioral intention based on the different applications, ANOVA was utilized. Prior to this analysis, assumptions (normal distribution and homogeneity of variances) were tested. For this purpose, firstly, whether there is an extreme value or not was examined. There were no extreme values in the dataset. After this process, in order to ensure the assumptions square transformation was utilized. Then, analyses were done and the findings were interpreted.

\subsection{Classroom Response Systems}

Within the scope of this research Kahoot, Quizizz and Plickers were chosen and applied as CRS. These CRSs were compared to each other and compared to the paper-based test. In this section, information about the CRSs is given.

\subsubsection{Kahoot}

The Kahoot application is available at https://kahoot.com/. In this application, multiple-choice tests can be created for students. The test is created by the instructor and a game pin number is given to the learners. Students can connect to this application with any computer, tablet or mobile phone with an internet connection and answer the questions in the test. Figure 1 and Figure 2 show screenshots of this application. 


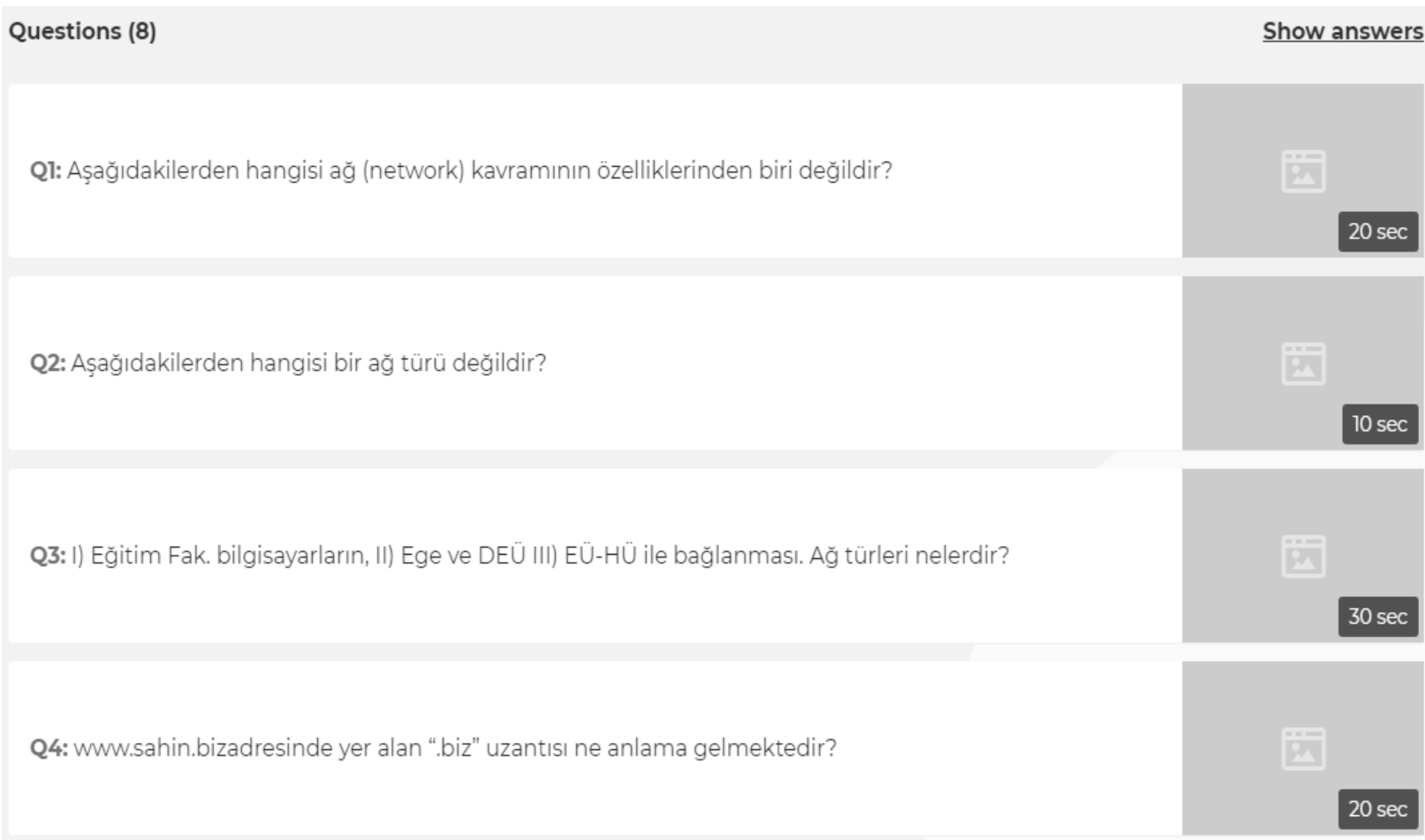

Figure 1. Kahoot application

Join with the Kahoot! app or at kahoot.it

with Came PIN:

\section{5}

\section{Kahoot!}

Figure 2. Pin number for Kahoot

As seen in Figure 1, a test consisting of eight questions about the "Information Technology Operating Systems" course was prepared and presented to the students and each question had four choices. Figure 2 shows the pin number for the students who want to join the game. The students entered the pin number at https://kahoot.it/ and after the test was started by the instructor, they answered the questions. There was a different time limit for each question as five, ten, twenty, and thirty seconds. While the Kahoot application was applied, the students saw the questions on the board via a projector and they responed the questions with their computers or mobile devices. Then, the details about the test results were presented to the students. Finally, the details of the application were introduced to the students and students developed a trial test in order to have an experience.

\subsubsection{Quizizz}

The Quizizz application is available at https://quizizz.com/. In this application, multiple-choice tests, puzzle, drag, and drop practice can be created for students. Figure 3 and Figure 4 show screenshots of this application. 


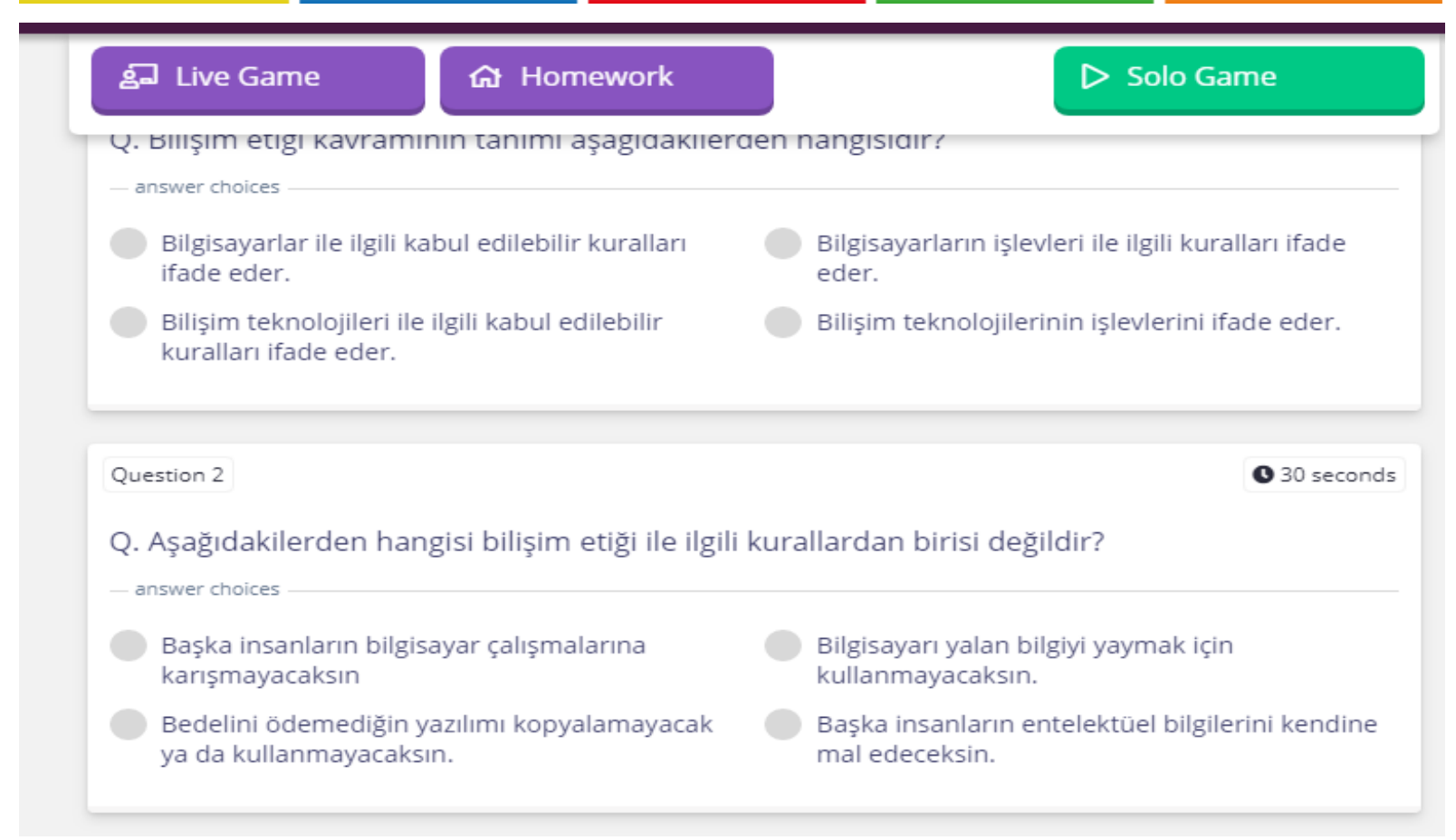

Figure 3. Quizizz test

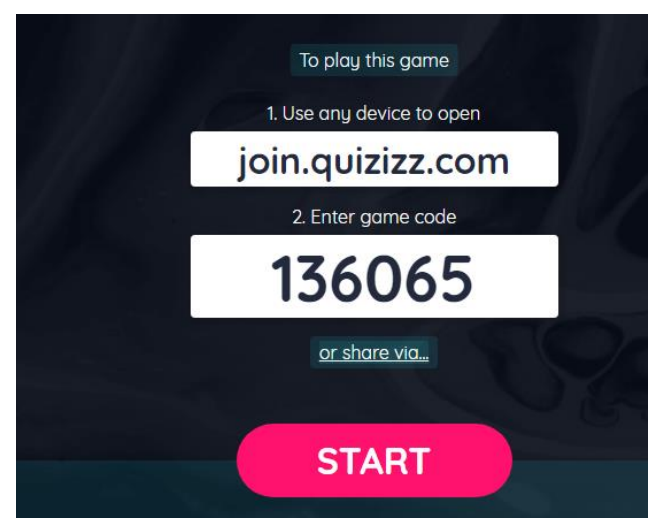

Figure 4. Pin number for Quizizz

As seen in Figure 3, a test consisting of eight questions about the "Information Technology Computer Networks" course was prepared and presented to the students. Figure 4 shows the pin number for the students who want to join the game. In this application, the students can see and response the test questions on their own computer tablet or mobile phone. With the projection device, instant scores and performances of the learners were displayed. And the details about the test results were presented to the students. Then, the details of the application were introduced to students and they developed a trial test in order for them to have experience.

\subsubsection{Plickers}

The Plickers application is available at https://get.plickers.com/. The Plickers application is similar to clickers, which is another CRS. However, each student is not given a clicker to carry out this practice; the students are given a paper-based defined to themselves with QR code. The questions were displayed by the instructor in an area that all students can see. Students indicated their responses by lifting this paper. The instructor read these QR codes with the help of a mobile device and the students' responses were seen directly. Not every student needs a computer, phone or tablet to perform this application. 


\subsection{Implementation Process}

The implementation period continued for four weeks. This study was conducted in "Information Technology" course and, about "Basic Concepts of Information Technology", "Operating Systems", "Computer Networks" and "Information Technology Ethics" subjects. Each week, the course subjects were explained and presented. In the next lesson, the students were tested in accordance with the applications. After the test, the students completed the scale forms online in order to determine the perceived usefulness and behavioral intention. In this study, the tests consisting of eight questions were prepared by the researcher. Totally four tests were developed, one for each subject. The aim of the development of these tests is to give the learners an opportunity toexperience with paper-based, Kahoot, Quizizz and Plickers applications. So the validity and reliability analyses were not performed. The implementation process is presented in Figure 5.
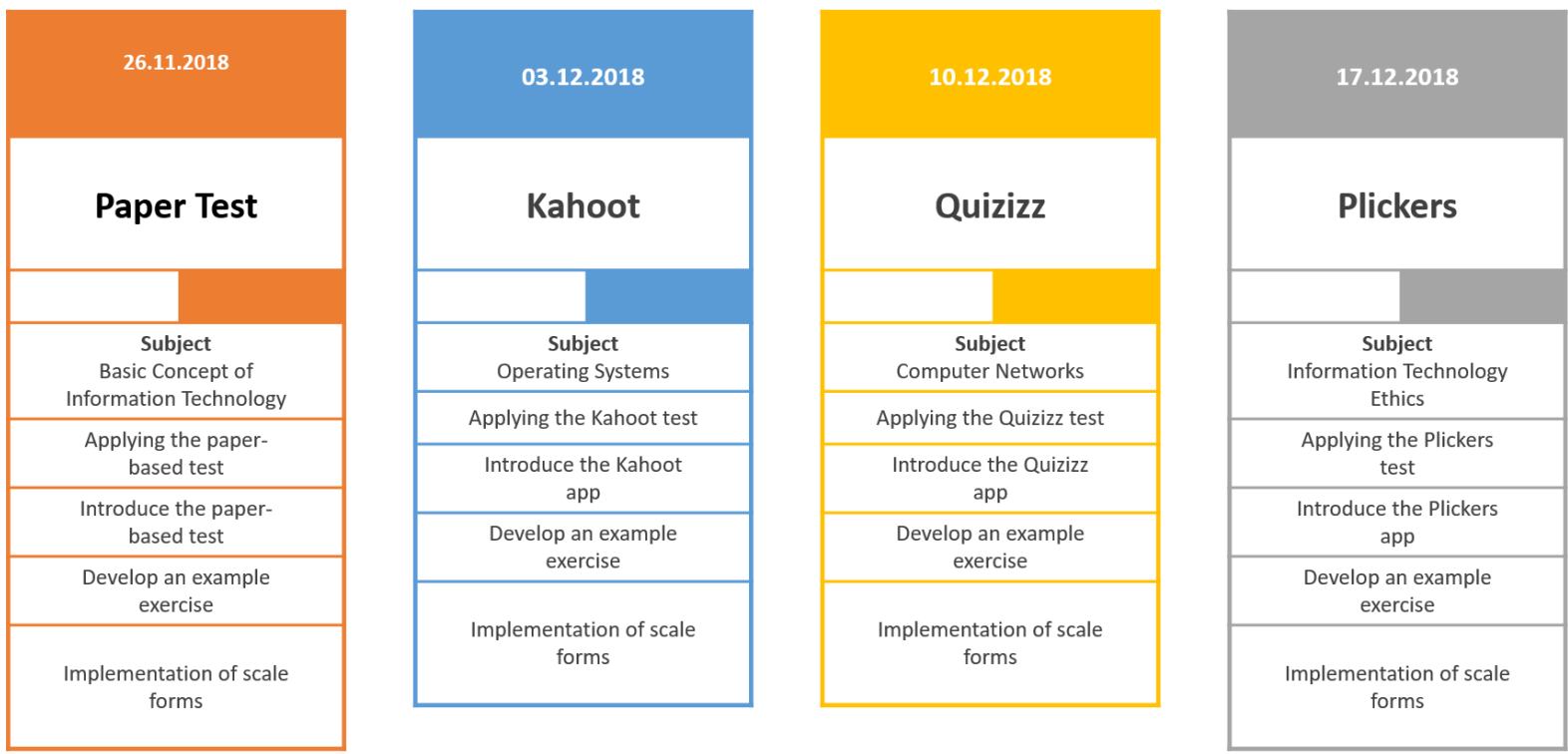

Figure 5. Implementation process

As it is shown in Figure 5, firstly the course subjects were explained. Then, the tests were applied in different types as paper-based, Kahoot, Quizizz, and Plickers app. In the next step, the application was introduced and students developed a practice at these applications. In the last stage, scale forms were applied to get the students' opinions about these practices. Detailed information about the findings is given in the findings section.

\section{FINDINGS}

This section contains detailed information about data analyses and findings. Firstly, descriptive information about the students who participated in the research are presented. Then, the findings obtained in the form of sub-problems is presented. Within the scope of this research, a fourweek implementation was conducted with the students. Information about students who participated in each practice is presented in Table 2.

Table 2. Descriptive information about the students who participated in each practice

\begin{tabular}{|c|c|c|c|c|c|}
\hline Division & & Paper-based test & Kahoot & Quizizz & Plickers \\
\hline Preschool Education & & 26 & 25 & 19 & 20 \\
\hline Guidance and Counseling & & 6 & 12 & 11 & 8 \\
\hline \multirow[t]{2}{*}{ Social Sciences Education } & & 29 & 23 & 29 & 26 \\
\hline & Total & 61 & 60 & 59 & 54 \\
\hline
\end{tabular}


As it is shown in Table 2, 61 students participated in the paper-based test, 60 students participated in Kahoot, 59 students participated in Quizizz and 54 students participated in Plickers practices. The analyses were executed based on these students' responses. The findings are presented as sub-problems.

\subsection{Findings about Perceived Usefulness}

The first one of the hypotheses included in this study is to examine the perceived usefulness of the applications used. In order to examine this, one-way analysis of variance was performed. Before the analysis, normal distribution and homogeneity of variances were tested. The results of these analyses are presented in Table 3.

Table 3. Results of the normal distribution and homogeneity of variances perceived usefulness

\begin{tabular}{llll}
\hline \multicolumn{2}{l}{ Descriptive statistics for normal distribution } & \multicolumn{2}{l}{ Homogenity of variance } \\
\hline Skewness & $-0,88$ & Levene statistic & 5,28 \\
Skewness std. error & 0,14 & Sig. & $0,00 *$ \\
Skewness/std error & $-6,29$ & & \\
Kurtosis & 1,41 & \\
Kurtosis std. error & 0,28 & \\
Kurtosis/std error & 5,03 & & \\
$*(p<0,05)$ & &
\end{tabular}

According to Table 3, it is seen that the assumptions required for performing one-way ANOVA (normal distribution and homogeneity of variance) are not ensured. In order to ensure these assumptions, Levene test results should be statistically insignificant and skewness/std. error and kurtosis/std. error values should be between $+1,96$ and $-1,96$ (Field, 2005). Transformations must be executed in order to provide the assumptions (Tabachnick, Fidell \& Ullman, 2007). As a result of the analyses, it was seen that the assumptions were not provided and the square transformation was performed. Results about normal distribution and homogeneity of variances after transformation are presented in Table 4.

Table 4. Results of the normal distribution and homogeneity of variances after transformation for perceived usefulness

\begin{tabular}{lccc}
\hline Descriptive statistics for normal distribution & \multicolumn{2}{l}{ Homogenity of variance } \\
\hline Skewness & $-0,08$ & Levene statistic & 2,28 \\
Skewness std. error & 0,14 & Sig. & 0,60 \\
Skewness/std error & $-0,57$ & & \\
Kurtosis & 0,27 & & \\
Kurtosis std. error & 0,28 & & \\
Kurtosis/std error & 0,95 & & \\
\hline
\end{tabular}

$p<0,05$

As it is shown in Table 4, after the transformations, both normal distribution and homogeneity of variances were obtained. After this stage, one-way ANOVA was performed. Descriptive statistics were presented based on raw data. Square values were utilized for performing oneway ANOVA. The descriptive information of the analysis is presented in Table 5.

Table 5. The descriptive information about perceived usefulness

\begin{tabular}{lccc}
\hline Application & $\mathrm{N}$ & $\overline{\mathrm{X}}$ & $\mathrm{SD}$ \\
\hline Paper-based test & 61 & 10,62 & 2,65 \\
Kahoot & 60 & 12,20 & 1,53 \\
Quizizz & 59 & 12,00 & 2,01 \\
Plickers & 54 & 11,11 & 1,90 \\
\hline
\end{tabular}


As it is seen in Table 5, it can be said that the averages of different applications (paper-based test $\bar{X}=119,77$; Kahoot $\bar{X}=151,77$; Quizizz $\bar{X}=148,00$; Plickers $\bar{X}=127,03$ ) are heuristically different. But, in order to use this expression, this situation needs to be statistically tested. The results of variance analysis are presented in Table 6.

Table 6. The results of variance analysis about perceived usefulness

\begin{tabular}{lllllll}
\hline & $\begin{array}{l}\text { Sum of } \\
\text { squares }\end{array}$ & df & $\begin{array}{l}\text { Mean } \\
\text { Square }\end{array}$ & F & Sig. & Differences \\
\hline $\begin{array}{l}\text { Between } \\
\text { Groups }\end{array}$ & 42614,34 & 3 & 14204,78 & 7,17 & 0,00 & $\begin{array}{l}\text { Kahoot>Paper-based test; } \\
\text { Kahoot>Plickers } \\
\text { Quizizz>Paper-based test }\end{array}$ \\
$\begin{array}{l}\text { Within } \\
\begin{array}{l}\text { Groups } \\
\text { Total }\end{array}\end{array}$ & 455885,05 & 230 & 1982,11 & & & \\
\hline$(p<0,05)$ & 498499,39 & 233 & & & & \\
\hline
\end{tabular}

According to Table 6 , it is seen that there is a statistically significant difference in perceived usefulness $(\mathrm{F}(3,230)=7,17 ; \mathrm{p}<0,05)$ according to the applications used in the classroom. In order to determine the difference between the groups, the Tukey test was conducted as a Post Hoc test. According to the results of the Tukey test, there is statistically significance. It was observed that a) the students' perceived usefulness to use Kahoot $(\bar{X}=12,20 ; s=1,53)$ instead of paper-based test $(\overline{\mathrm{X}}=10,62 ; \mathrm{s}=2,65)$; $\mathrm{b})$ the students' perceived usefulness to use Kahoot $(\overline{\mathrm{X}}=$ $12,20 ; \mathrm{s}=1,53)$ instead of Plickers $(\overline{\mathrm{X}}=11,11 ; \mathrm{s}=1,90)$; and $\mathrm{c})$ the students' perceived usefulness to use Quizizz ( $\overline{\mathrm{X}}=12,00 ; \mathrm{s}=2,01)$ instead of paper-based test $(\overline{\mathrm{X}}=10,62 ; \mathrm{s}=2,65)$ were statistically higher.

\subsection{Findings about Behavioral Intention}

The other hypotheses included in this study is to examine the behavioral intention of the applications used. In order to examine this, one-way ANOVA was performed. Before the analysis, normal distribution and homogeneity of variances were tested. The results of these analyses are presented in Table 7.

Table 7. Results of the normal distribution and homogeneity of variances behavioral intention

\begin{tabular}{llll}
\hline \multicolumn{2}{l}{ Descriptive statistics for normal distribution } & \multicolumn{3}{l}{ Homogenity of variance } \\
\hline Skewness & $-0,73$ & Levene statistic & 3,34 \\
Skewness std. error & 0,14 & Sig. & $0,01^{*}$ \\
Skewness/std error & $-5,21$ & & \\
Kurtosis & 0,50 & & \\
Kurtosis std. error & 0,28 & & \\
Kurtosis/std error & 1,79 & & \\
\hline${ }^{*}<<0,05$ & &
\end{tabular}

According to Table 7, as a result of the analyses, it was seen that the assumptions were not ensured and square transformation was performed. Results about normal distribution and homogeneity of variances after transformation is presented in Table 8.

As it is shown in Table 8, after the transrormations, both normal distribution and homogeneity of variances were obtained. After this stage, one-way ANOVA was performed. Descriptive statistics were presented based on raw data. Square values were utilized for performing oneway ANOVA. The descriptive information of the analysis is presented in Table 9. 
Table 8. Results of the normal distribution and homogeneity of variances after transformation for behavioral intention

\begin{tabular}{lllc}
\hline \multicolumn{2}{l}{ Descriptive statistics for normal distribution } & Homogenity of variance \\
\hline Skewness & 0,06 & Levene statistic & 1,95 \\
Skewness std. error & 0,14 & Sig. & 0,10 \\
Skewness/std error & 0,43 & & \\
Kurtosis & $-0,29$ & \\
Kurtosis std. error & 0,28 & & \\
Kurtosis/std error & $-1,04$ & & \\
\hline$p<0,05$ & &
\end{tabular}

Table 9. The descriptive information about behavioral intention

\begin{tabular}{lccc}
\hline Application & $\mathrm{N}$ & $\overline{\mathrm{X}}$ & $\mathrm{SD}$ \\
\hline Paper-based test & 61 & 9,86 & 3,37 \\
Kahoot & 60 & 11,55 & 2,21 \\
Quizizz & 59 & 11,28 & 2,43 \\
Plickers & 54 & 10,50 & 2,60 \\
\hline
\end{tabular}

As can be seen in Table 9, it can be said that the averages of different applications (paper-based test $\bar{X}=108,59$; Kahoot $\bar{X}=138,22$; Quizizz $\bar{X}=133,25$; Plickers $\bar{X}=116,91$ ) are heuristically different. But, in order to use this expression, this situation needs to be statistically tested. The results of variance analysis are presented in Table 10.

Table 10. The results of variance analysis about behavioral intention

\begin{tabular}{lllllll}
\hline & Sum of squares & df & Mean Square & F & Sig. & Differences \\
\hline $\begin{array}{l}\text { Between } \\
\text { Groups }\end{array}$ & 34356,66 & 3 & 11452,22 & 3,88 & 0,1 & None \\
$\begin{array}{l}\text { Within } \\
\text { Groups }\end{array}$ & 678522,66 & 230 & 2950,01 & & & \\
Total & 712879,32 & 233 & & & & \\
\hline$(\mathrm{p}<0,05)$ & & & & & &
\end{tabular}

According to Table 10, it is seen that there is not a statistically significant difference in behavioral intention $(F(3,230)=3,88 ; p>0,05)$ according to the applications used in classroom.

\section{DISCUSSION and CONCLUSION}

CRSs provide feedback to instructors on what subjects are needed for extra teaching and in which topics students are successful (Bartsch \& Murphy, 2011). Besides, CRSs give learners immediate feedback on multiple-choice questions (Judson \& Sawada, 2002). This feedbacks provide important tips for formative assessment. In order to use these systems, in the first step teachers and candidate teachers should be informed about these systems or environments. In the second step, they should think that these systems are useful and they want to use them. So, in the context of this research, the students had an experience with different CRSs as Kahoot, Quizizz, and Plickers. And then students' perceived usefulness and behavioral intention structures about the CRSs were investigated. In the literature, it is concluded that the use of CRS is easy to use, useful by learners, increasing interaction and engagement (Siau et al., 2006; Martyn, 2007; King \& Robinson, 2009; Sievers et al., 2012; Keyssner \& Dunn, 2013; Wu, Wu, $\& \mathrm{Li}, 2019$ ). CRS tools provide immediate feedback (Kay, 2009). Black and William (1998) stated that quality feedback is the key feature of FA. So, these tools can be utilized as a FA tool 
in the classroom. And also, more enjoyable and competitive classroom climate can be created through CRS.

This research was conducted in a computer laboratory with internet connection. So, there was no problem with the internet connection or physical infrastructure. CRSs are technologies that are used to promote active learning (Martyn, 2007). So, learning environments should be structured to encourage students and increase students' engagement. And also, learners must be an active part of the learning process in these environments. However, it should be noted that the essential hardware and physical infrastructure should be provided when using these systems because the inability to provide productive classroom environments is one of the problems encountered in the effective use of these systems (Feldman \& Capobianco, 2003). If the researcher/instructor/tutor wants to use CRS, it is important that each student must have a mobile device or computer with an internet connection. In addition, if the questions will be displayed to the students on a single screen, the screen should be positioned where all the students can see the questions.

Nowadays the CRSs present much detailed information to the instructors such as a) individual performance, $b$ ) performance of the group, c) correct response rate on for each question, and d) the response time of each question. This information is very important for the application. Based on this information, environments or applications can be reconstructed or reorganized. And for these systems, one of the usage points to be considered is to give the student enough response time (Lucke, Keyssner, \& Dunn, 2013). Otherwise, the effectiveness of the learning environment will be affected negatively. Besides, the addition of the elements of gamification as a leader board, and badges provides opportunities for the learning environment to make it more enjoyable and to see their status according to their peers. In addition to these, the studies and applications should be integrated well into the curriculum (Sims, 2003).

Within the scope of this study, perceived usefulness and behavioral intention of using CRS were examined by comparing both the paper-based test and each other unlike studies in the literature. This research is limited to perceived usefulness and behavioral intention structures of the acceptance and adoption theories and models. For future research, the other structures of the acceptance and adoption theories and models as perceived ease of use, social impact, content and etc. structures could be examined. In addition to this, these structures can be tested by structural equation modeling.

This study was structured as survey research. And findings are limited to the self-report scale data. In this context for future research, experimental design can be constructed or organized. In this way, the effectiveness of CRSs systems in the context of formative assessment can be demonstrated more clearly. The other suggestion is to conduct this research with a higher number of students/participants group. Thus, it may make possible to present more clear findings which is generalizable to the population.

\section{ORCID}

Muhittin Şahin (D) https://orcid.org/0000-0002-9462-1953

\section{REFERENCES}

Bartsch, R. A., \& Murphy, W. (2011). Examining the effects of an electronic classroom response system on student engagement and performance. Journal of Educational Computing Research, 44(1), 25-33.

Bayrak, F., \& Yurdugül, H. (2016). Web-tabanlı öz-değerlendirme sisteminde öğrenenlerin özmüdahale algisi ve test alma davranişlarinin başari üzerine etkisi [The effect of selfintervention perception and test taking behaviour on success in web-based self- 
assessment system]. Ĕgitimde ve Psikolojide Ölçme ve Değerlendirme Dergisi, 7(1), 221236.

Bayrak, F., \& Yurdugül, H. (2016). Web-tabanlı öz-değerlendirme sisteminde öğrenci uyarı indeksini temel alan öğrenme analitiği modülünün tasarlanması [Designing at the micro level learning analytics module for web-based self-assessment system]. Eğitim Teknolojisi Kuram ve Uygulama, 6(2), 85-99.

Beatty, I. D., Gerace, W. J., Leonard, W. J., \& Dufresne, R. J. (2006). Designing effective questions for classroom response system teaching. American Journal of Physics, 74(1), 31-39.

Black, P., \& Wiliam, D. (1998). Assessment and classroom learning. Assessment in Education: Principles, Policy \& Practice, 5(1), 7-74.

Bransford, J. D., Brown, A. L., \& Cocking, R. R. (2000). "How People Learn: Brain, Mind, Experience, and School", Expanded Edition, Washington, DC: National Academy Press.

Cheng, L. T., \& Wang, J. W. (2019). Enhancing learning performance through classroom response systems: The effect of knowledge type and social presence. The International Journal of Management Education, 17(1), 103-118.

Deal, A. (2007). A teaching with technology white paper: classroom response systems. Office of Technology for Education. Eberly Center for TeachingExcellence. Retrieved June, 25, 2009.

Feldman, A., \& Capobianco, B. (2003). Real-time formative assessment: A study of teachers' use of an electronic response system to facilitate serious discussion about physics concepts. In Annual Meeting of the American Educational Research Association (Chicago, IL, 2003).

Field, A. (2005). Discovering statistics using SPSS. Sage Publication Ltd.

Fishbein, M., \& Ajzen, I. (1975). Belief, attitude, intention and behavior: an introduction to theory and research: Addison-Wesley, Reading MA.

Fraenkel, J. R., Wallen, N. E., \& Hyun, H. H. (2011). How to design and evaluate research in education. New York: McGraw-Hill Humanities/Social Sciences/Languages.

Fuller, J. S., \& Dawson, K. M. (2017). Student response systems for formative assessment: Literature-based strategies and findings from a middle school implementation. Contemporary Educational Technology, 8(4), 370-389.

Judson, E., \& Sawada, D. (2002). Learning from past and present: Electronic response systems in college lecture halls. Journal of Computers in Mathematics and Science Teaching, 21(2), 167-181.

Kay, R. H. (2009). Examining gender differences in attitudes toward interactive classroom communications systems (ICCS). Computers \& Education, 52(4), 730-740.

Kay, R. H., \& LeSage, A. (2009). Examining the benefits and challenges of using audience response systems: A review of the literature. Computers \& Education, 53(3), 819-827.

King, S. O., \& Robinson, C. L. (2009). 'Pretty Lights' and Maths! Increasing student engagement and enhancing learning through the use of electronic voting systems. Computers \& Education, 53(1), 189-199.

Lucke, T., Keyssner, U., \& Dunn, P. (2013, October). The use of a classroom response system to more effectively flip the classroom. In 2013 IEEE Frontiers in Education Conference (FIE) (pp. 491-495). IEEE.

Martyn, M. (2007). Clickers in the classroom: An active learning approach. Educause Quarterly, 30(2), 71.

Nunnally, J. C., \& Bernstein, I. H. (1994). Psychometric theory. New York: McGraw-Hill.

Petto, A. J. (2019). Technology meets pedagogy: Comparing classroom response systems. Journal of College Science Teaching, 48(4), 55-63. 
Pinchok, N., \& Brandt, W. C. (2009). Connecting formative assessment research to practice: an introductory guide for educators. Learning Point Associates.

Rogers, E. (2003). Diffusion of innovation. New York: Free Press.

Siau, K., Sheng, H., \& Nah, F. H. (2006). Use of a classroom response system to enhance classroom interactivity. IEEE Transactions on Education, 49(3), 398-403.

Sievers, M., Reinhardt, W., Kundisch, D., \& Herrmann, P. (2012). Developing electronic classroom response apps for a wide variety of mobile devices: Lessons learned from the PINGO project. In mLearn (Vol. 955, pp. 248-251).

Sims, R. (2003). Promises of interactivity: Aligning learner perceptions and expectations with strategies for flexible and online learning. Distance Education, 24(1), 87-103.

Tabachnick, B. G., Fidell, L. S., \& Ullman, J. B. (2007). Using multivariate statistics (Vol. 5). Boston, MA: Pearson.

Usluel, Y. K., \& Mazman, S. G. (2010). Eğitimde yeniliklerin yayılımı, kabulü ve benimsenmesi sürecinde yer alan öğeler: bir içerik analizi çalışması. Çukurova University Faculty of Education Journal, 3(39), 60-74.

Vetterick, J., Garbe, M., Dähn, A., \& Cap, C. H. (2014). Classroom response systems in the wild: technical and non-technical observations. International Journal of Interactive Mobile Technologies (iJIM), 8(1), 21-25.

Wu, Y. C. J., Wu, T., \& Li, Y. (2019). Impact of using classroom response systems on students' entrepreneurship learning experience. Computers in Human Behavior, 92(2019), 634-645.

Yang, X., Fu, J., Rodríguez-Sedano, F., \& Conde, M. Á. (2019, October). Enhancing Students' Academic Performance through Teamwork and Classroom Response Systems: Case Study with Chinese Students. In Proceedings of the Seventh International Conference on Technological Ecosystems for Enhancing Multiculturality (pp. 732-737). ACM.

Yılmaz, R., \& Karaoğlan Yılmaz, F. G. (2019). Bir oyunlaştırma ve biçimlendirici değerlendirme aracı olarak kahoot kullanımına yönelik öğretmen adaylarının görüşlerinin incelenmesi. II. Uluslararası Eğitimde ve Kültürde Akademik Çalışmalar Sempozyumu (331-337). Denizli, Türkiye

Yurdugül, H. \& Bayrak, F. (2014). İlkokul öğrencilerinin web tabanlı biçimlendirmeye dönük değerlendirme sistemini kabulleri [The acceptance of web based formative assessment system for primary school students]. Journal of Educational Sciences \& Practices, 2014, $13-26$. 